\title{
Use of Factor Analysis to Identify Sources Controlling Groundwater Chemistry in The Shallow Coastal Plain Aquifer, Western Saudi Arabia
}

\author{
Tariq H. Bayumi and Mahmoud S. Alyamani \\ Department of Hydrogeology, Faculty of Earth Sciences, \\ King Abdulaziz University, Jeddah, Saudi Arabia \\ Received: 28/12/2002 Revised: 26/1/2003 Accepted: 28/6/2003
}

\begin{abstract}
R-mode Factor analysis was used to interpret collected data concerning the groundwater chemistry from the shallow coastal plain aquifer and relating them to specific factors that brought about changes in the water quality. Five factors, accounting for nearly $81 \%$ of the total variance, were identified. These factors reflect different chemical processes that control the groundwater chemistry. Factor 1 reflects the most important process; namely the intensive evaporation which resulted in the highly mineralized water. Other processes that could be associated with this factor include the chemical weathering of silicate minerals, ion exchange reactions and mixing processes. Factor 2 represents the precipitation and dissolution of carbonate minerals (calcite and dolomite). Factors 1 and 2 could be considered the major factors controlling the chemical composition of the groundwater since they account for $50 \%$ of the total variance and together, they produce a chemical population ranging from low to extremely high saline water, which is confirmed by the chemical analysis results. The other three factors, which dominate the chemical processes, include oxidation of pyrite, groundwater pollution and solubility of silica. They could, therefore, be considered as contributor factors to the groundwater chemistry in an overall scale. Distribution score maps of the first four factors were constructed to delineate their relative spatial impact.
\end{abstract}

\section{Introduction}

In Jeddah city, groundwater salinity is extremely high and is characterized by spatial variations of the concentration of major and minor ions. In some areas, 
the groundwater salinity may exceed that of the Red Sea water. The occurrence of the highly mineralization shallow groundwater in the city often creates serious problems to various constructions. Such problems will continue as long as these constructions have contact with the groundwater. Bayumi et al. (2000) introduced a comprehensive study on the shallow coastal plain aquifer. Several conclusions as well as possible factors affecting groundwater quality were proposed to explain the hydrogeological and hydrochemical aspects that control the present conditions of the aquifer. Similar results that concern the groundwater chemistry have been reported by Basamed (2001), who also outlined the complexity of the chemical evolution of the groundwater in the northern part of the city. The wide variation in the groundwater chemistry, suggests that more than a single source might be operative to control the groundwater quality. Such sources include the high rate of evaporation, irrigation practices, subsurface flows from the eastern wadis and probably salt water intrusion in areas closer to the coast. Additional recharge of this aquifer in populated region will involve indirect supply from domestic usage. This source of recharge may be significant since large areas, especially in the central parts, have not been covered by sewage water networks. Instead septic tanks are used. Consideration of these various possible factors could cause rather complexity and confusion while studying the chemical evolution of the existing system.

In the presence of substantially large amount of base information concerning the groundwater chemistry, and the limitation associated with the classical graphical approaches, which often allow using a finite number of variables (Ashley and Lloyd, 1978; Dalton and Upchurch, 1978; and Lawrence and Upchurch, 1982), multivariate techniques may be useful and come into consideration as an essential tool because the relative importance combinations of chemical and non-chemical variables can be evaluated.

In the present study factor analysis was adopted to inter-relate the available chemical elements in order to define the possible potential process(es) that might have an influence on groundwater chemistry as well as to delineate areas that are affected by them.

\section{Area Description}

The present work was conducted on a $500 \mathrm{~km}^{2}$ portion of the coastal plain aquifer in Jeddah city in the Western Province of Saudi Arabia (Fig.1).

The climate is typically arid. The average annual rainfall is about $60 \mathrm{~mm}$. It is irregular and torrential in nature when it occurs. The rainfall season, from November to March, December and January, receives nearly $70 \%$ of the annual rainfall. Owing to shallow water table condition a considerable amount of rain- 


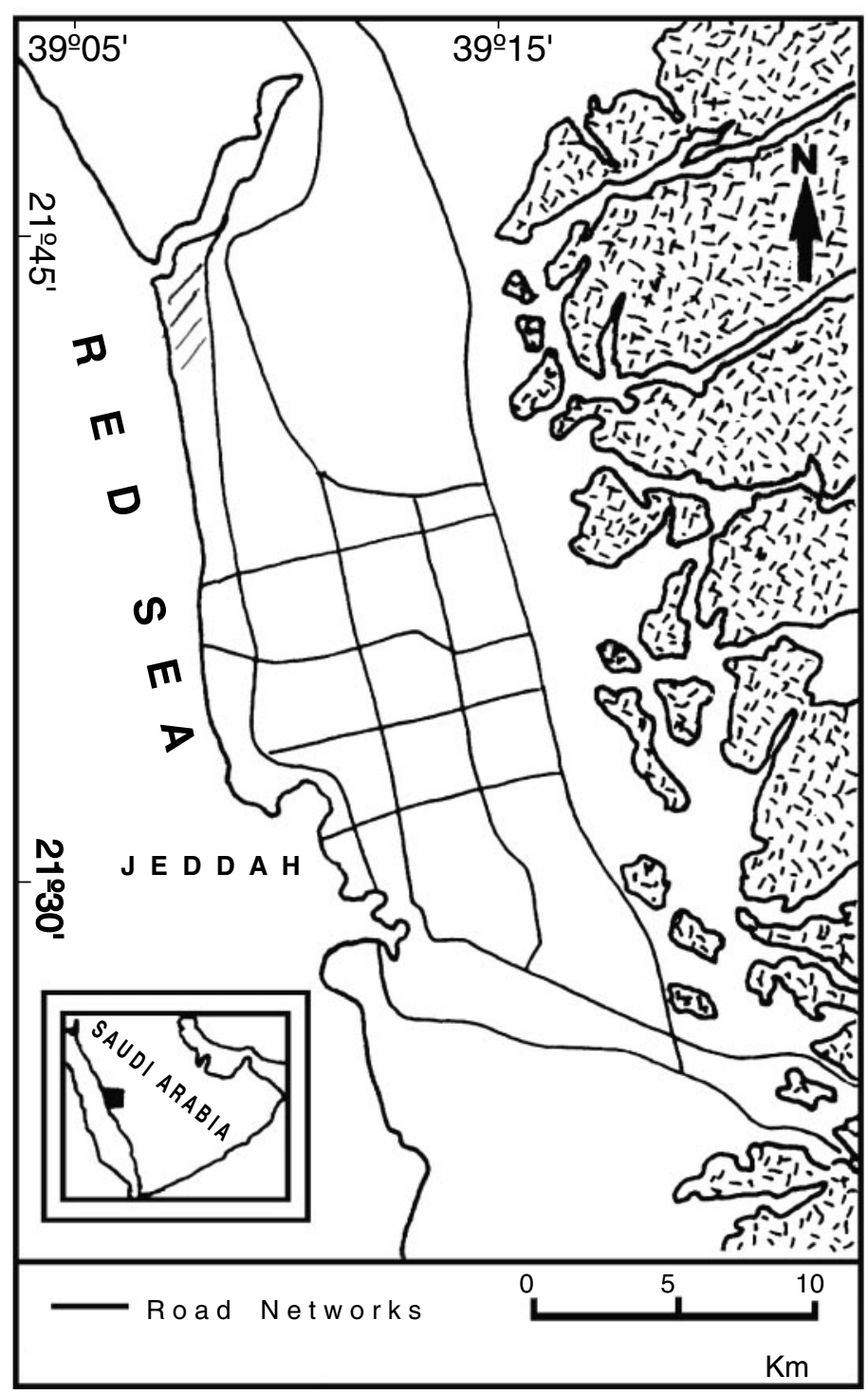

FIG. 1. Location map of the study area. 
fall is channeled into surface water. Flash floods which generate in the eastern wadis drain into the plain and occasionally cause heavy destruction in the city. Temperatures are usually high; the mean maximum temperature is about $38^{\circ} \mathrm{C}$ in July. This gives rise to important evaporation processes both qualitatively and quantitatively, which affects the water balance as well as the water quality in an overall scale.

The plain is bounded on its eastern edge by elevated basement outcrops. Generally, the ground elevation decreases toward the western direction from in excess of 300 m.a.s.l to about 4 m.a.s.l. Two topographic regions are recognized; the coastal lowlands and the eastern highlands. The coastal plain aquifer is rather shallow, and the groundwater occurs within highly permeable formations; these are surficial soil, sandy gravel and coralline limestone. Solution cavities are observed in the limestone. In the coastal lowlands, the water-bearing formation is thin and may be discontinuous, whereas towards the eastern part the alluvium deposits are rather thick and continuous. Clay layers act as confining beds, whereas sandy silt beds serve as aquitards. Shallow water table usually exists above clay beds, which prevents deep percolation of groundwater. The aquifer is mainly unconfined and the water level depth ranges from less than one meter to 7 meters. Groundwater flows (Fig.2) toward the west under steep hydraulic gradient with an average of about 0.03 (Bayumi et al. 2000).

The general chemical character of the groundwater shows higher concentrations for most of the major ions. Some of the wells that are located in the north, northwest and southwest yielded extremely high saline water, which almost exceeds the salinity of the Red Sea water (Fig.3). Comparing the water table map with The Total Dissolved Solids (TDS) distribution map shows the degree of mineralization does not increase generally in a down-gradient direction, confirming that localized effects that previously mentioned are taking place in the area.

Based on the previous investigations carried out by Hacker et al. (1984), Moore and Al-Rehaili (1989) and Al-Quahtani (1998) two main lithology units exist:

- Quaternary sedimentary formations in the central, western and northern parts. They comprise mainly clastic alluvial sand and gravel in the central and southern regions and coralline limestone rocks together with sabkha soils in the western and northwestern parts (Fig. 4). These deposits bound and overlie the Precambrian rocks from the west. They are of continental origin while on the alluvial plain, start to overlap and mix with marine rocks and soil in the coastal zone. The sabkha soil was deposited in marine environment. It forms a narrow strip extending less than $1 \mathrm{~km}$, with common salt brine potholes. Clay seems or lenses may be found in this soil at various depths. On the other hand, the limestone rocks are found as flat extensive ( $>10 \mathrm{~km}$ wide) plateau, with few 


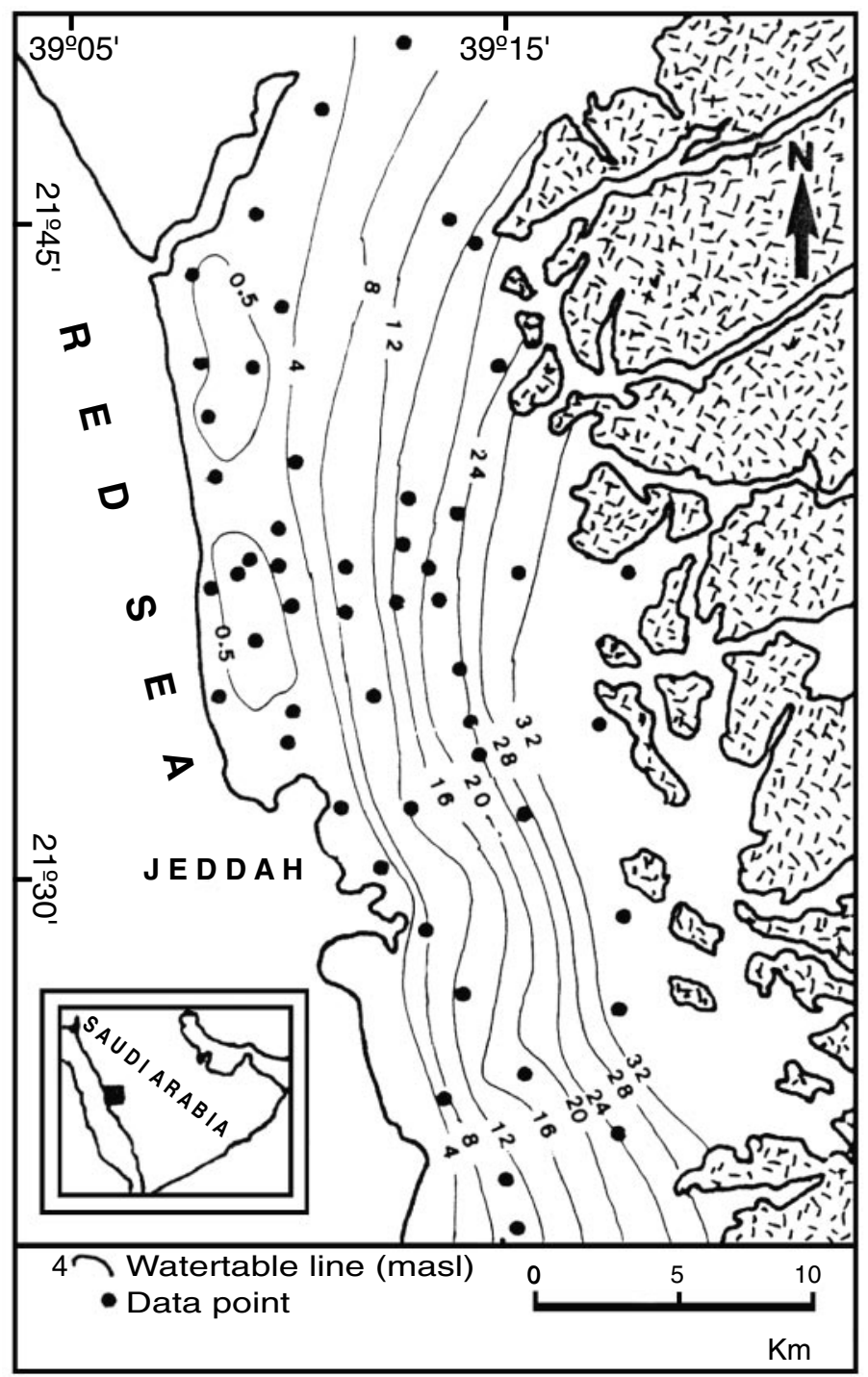

Fig. 2. Water table map. 


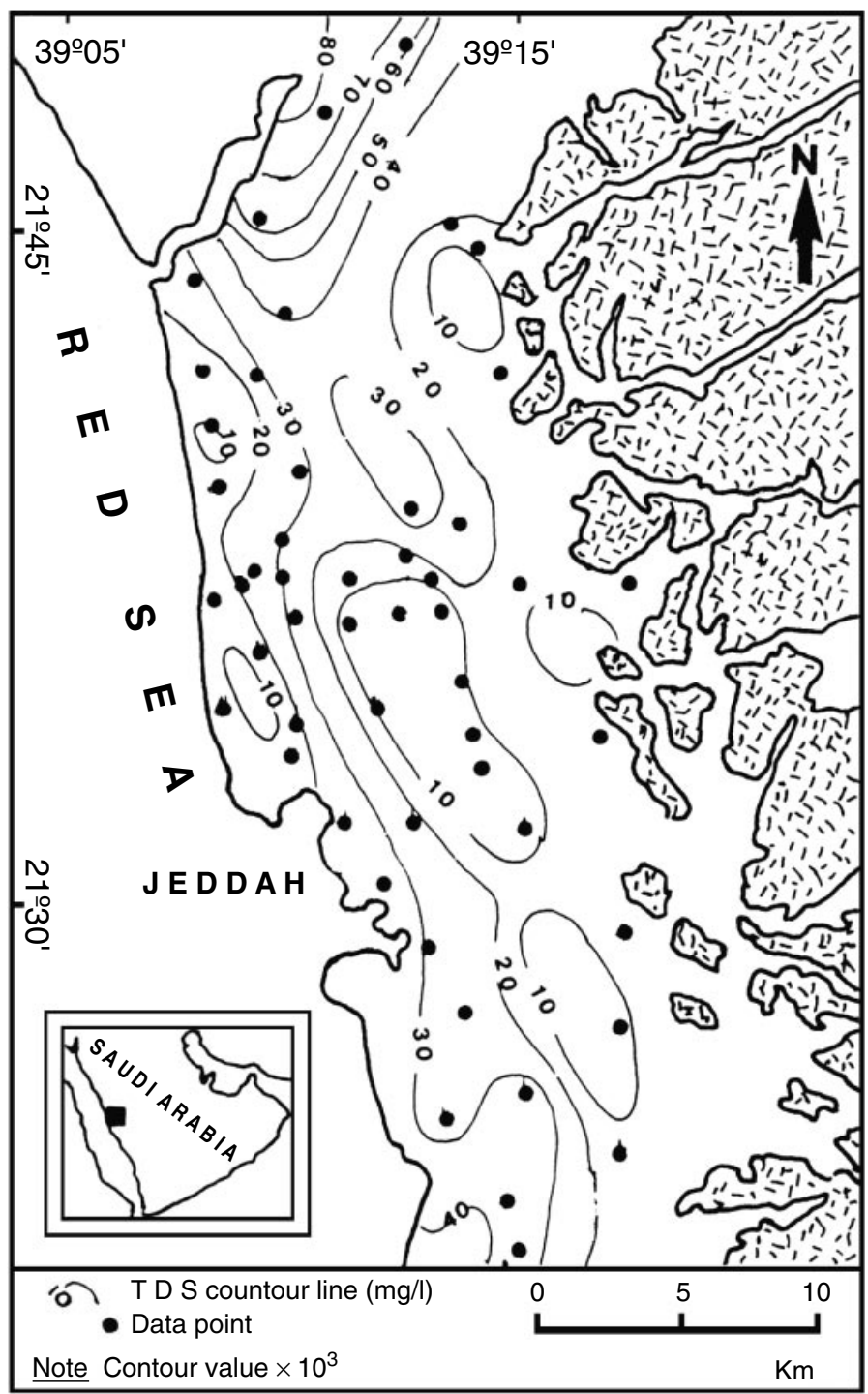

FIG. 3. Total Dissolved Solids (TDS) distribution map. 


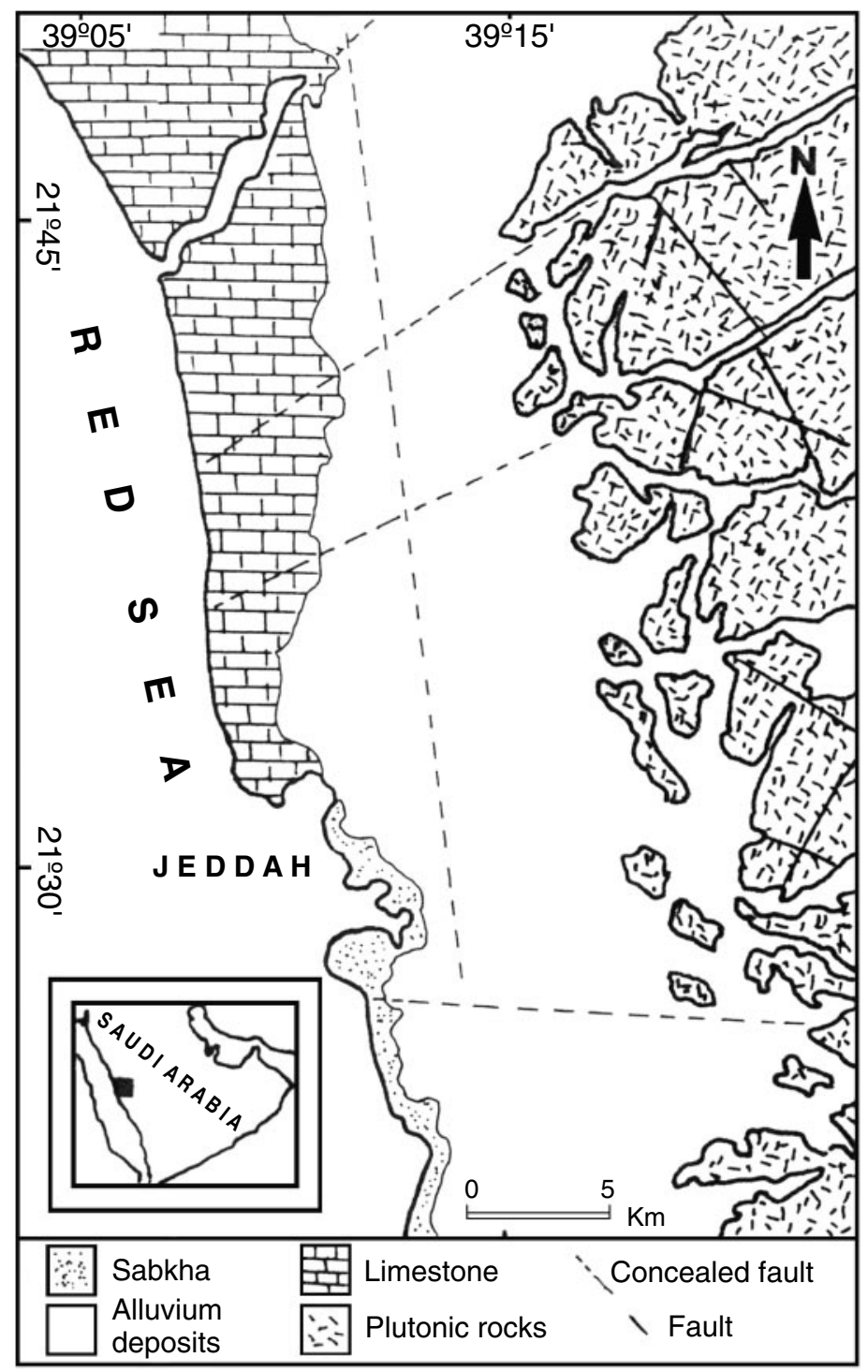

FIG. 4. Generalized geologic map of the area. 
depressions that make sabkha environments. Shells, skeletons and animal borings are characteristics of these rocks in the top three meters where exposed by trenches and excavations. The contact between these rocks and the alluvial deposits is gradational because sands and gravels of the alluvial plain overlie these rocks and intefinger with them vertically and horizontally.

- Plutonic rocks that make most of the intrusive Precambrian rocks in the area consist mainly of quartz diorite and diorite.

The Red Sea fault system has affected most of the rock units east of Jeddah. The faults form three main sets trending approximately northwest, northeast and north. In the coastal plain there are concealed fault systems parallel and perpendicular to the Red Sea. Swarms of dikes and sills also affect the basement rocks.

\section{Sampling and Methodology}

Fifty groundwater samples were collected from wells belonging to the $\mathrm{Mu}$ nicipality of Jeddah city. All the samples were analyzed for major and some minor constituents, following the standard analysis methods. Detailed of analytical methods used are given in Bayumi et al. (2000). Additionally, saturation indices of calcite, $\left(\mathrm{SI}_{\mathrm{c}}\right)$ dolomite $\left(\mathrm{SI}_{\mathrm{d}}\right)$, halite $\left(\mathrm{SI}_{\mathrm{h}}\right)$ and gypsum $\left(\mathrm{SI}_{\mathrm{g}}\right)$ as well as the field measurements, including $\mathrm{pH}$, electrical conductivity (EC) and groundwater temperature are reported in the present study (Table 1).

TABLE 1. Summary statistics of the chemical analyses results of the groundwater, field measurements and the average chemical composition of the Red Sea water.

\begin{tabular}{|l|c|c|c|c|c|}
\hline Elements & Unit & Minimum & Maximum & Mean & $\begin{array}{c}\text { Average chemical } \\
\text { composition of the } \\
\text { Red Sea water }\end{array}$ \\
\hline $\mathrm{C}^{-}$ & $\mathrm{Mg} / 1$ & 226.2 & 47950.0 & 8705.9 & 22747 \\
\hline $\mathrm{Mg}^{2+}$ & $=$ & 16.8 & 2948.0 & 512.4 & 1422 \\
\hline $\mathrm{Na}^{+}$ & $=$ & 171.7 & 20214.0 & 4579.2 & 11440 \\
\hline $\mathrm{Ca}^{2+}$ & $=$ & 32.2 & 5631.0 & 825.6 & 554 \\
\hline $\mathrm{K}^{+}$ & $=$ & 2.3 & 280.4 & 65 & 355 \\
\hline $\mathrm{NO}_{3}^{-}$ & $=$ & 7.40 & 586.5 & 110 & - \\
\hline $\mathrm{Fe}^{2+}$ & $=$ & 0.01 & 2.5 & 0.22 & 0.41 \\
\hline $\mathrm{SO}_{4}^{2-}$ & $=$ & 226.6 & 4631.2 & 1583 & 3140 \\
\hline $\mathrm{HCO}_{3}^{-}$ & $=$ & 56.8 & 897.3 & 238.1 & 136 \\
\hline $\mathrm{NH}_{4}^{+}$ & $=$ & 0.0 & 87.3 & 7.59 & 0.06 \\
\hline $\mathrm{SiO}_{2}$ & $=$ & 4.2 & 64.7 & 21.2 & 2.3 \\
\hline
\end{tabular}


Table 1. Contd.

\begin{tabular}{|l|c|c|c|c|c|}
\hline Elements & Unit & Minimum & Maximum & Mean & $\begin{array}{c}\text { Average chemical } \\
\text { composition of the } \\
\text { Red Sea water }\end{array}$ \\
\hline $\mathrm{PO}_{4}^{3-}$ & $=$ & 0.002 & 7.20 & 0.217 & 0.07 \\
\hline Temp. & ${ }^{\circ} \mathrm{C}$ & 28.1 & 38.4 & 30.2 & - \\
\hline $\mathrm{EC}$ & $\mu \mathrm{S} / \mathrm{cm}$ & 1355.0 & 94000 & 23104.0 & - \\
\hline $\mathrm{TDS}$ & $\mathrm{Mg} / 1$ & 1279 & 78763 & 16647.0 & 39797 \\
\hline $\mathrm{SI}_{\mathrm{d}}$ & - & -0.49 & 3.76 & 1.01 & - \\
\hline $\mathrm{SI}_{\mathrm{c}}$ & - & -0.23 & 1.40 & 0.45 & - \\
\hline $\mathrm{SI}_{\mathrm{g}}$ & - & -2.2 & 0.18 & -0.63 & - \\
\hline $\mathrm{SI}_{\mathrm{h}}$ & - & -5.61 & -1.82 & -3.98 & - \\
\hline $\mathrm{PH}$ & - & 6.67 & 8.50 & 7.53 & - \\
\hline
\end{tabular}

$\mathrm{SI}_{\mathrm{d}}=$ Saturation index of dolomite, $\mathrm{SI}_{\mathrm{c}}=$ Saturation index of calcite, $\mathrm{SI}_{\mathrm{g}}=$ Saturation index of gypsum, $\mathrm{SI}_{\mathrm{h}}=$ Saturation index of halite.

On the other hand, the X-Ray Diffraction analysis (XRD) was run on soil samples obtained from encrustations existing in the sabkha soils as well as in northwestern area, where the water table is rather shallow or at the ground surface. The XRD results indicate that calcite, dolomite and gypsum with small amount of halite are very common evaporitic salts in surficial soils. However, calculation of saturation indices show that most of the groundwater samples tend to precipitate calcite, dolomite and partly gypsum, but capable of dissolving gypsum and halite. Precipitation of halite, however, cannot be ruled out although this mineral has not reached the equilibrium phase.

A summary statistics of these components and the average chemical composition of the Red Sea water are presented in Table 1.

\section{Factor Analysis (R-mode)}

Over the past 30 years, Factor analysis (FA) has been successfully used to sort out the hydrochemical processes and relationships of collected groundwater data (Morin et al., 1979, Lawrence and Upchurch, 1982; Saad and Turgeon, 1988; and Deverel 1989). The goal of FA is to simplify the quantitative description of a system by determining the minimum number of new variables necessary to reproduce various attributes of the data. These procedures reduce the original data matrix from one having $(n)$ variables necessary to describe the $(N)$ samples to a matrix with $(\mathrm{m})$ factors $(\mathrm{m}<\mathrm{n})$ for each of the $(\mathrm{N})$ samples. Furthermore, the objective of 
factor analysis is to transform the variables so that the axes become orthogonal, which then allows the definition of new independent variables. In doing so, the first factor is chosen to explain as much as possible of the total variance of the observations, the second factor to explain as much as possible of the residual variance, and so forth. In other words, the first factor is determined such that the sum of squares of the projections of the points on the factor is maximum (factor loadings). Next, to define the second factor, the points are projected on a plane orthogonal to the first factor and so on for the other factors, each explaining less and less of the total variance. On the other hand, the sum of squares of the factor loadings for each variable is the communality and reflects the proportion of the total variability of each variable accounted for by the factoring.

The FA subsumes a fairly large variety of procedures. It follows three main steps, namely: extraction initial factors, rotation of factors and calculation of each factor scores. In the present work, factor extraction was done by principal components; whereas, varimax rotation with Kaiser normalization was used for orthogonal rotation and results in factors that are uncorrelated (Usunoff and Guzman, 1989). The factor scores that are computed for each observation (Kloven, 1975; and Johnston, 1980) indicate the importance of each factor at that observation site. Dalton and Upchurch (1978) outlined the importance of factor scores and their relations to potential of the processes described by each factor. Negative scores reflect areas essentially unaffected by the processes and positive scores reflect regions most affected. On the other hand, zero values indicate an average degree of influence by the factor. R-mode procedure was applied for finding a comparison of the relations among the variables in terms of the samples.

Prior to FA, the data was standardized in order to remove the effects of using different metrics in describing the various variables as well as to avoid the wide range occurring in their values. The standardized values have a mean value of zero and standard deviation of one. A detailed mathematical treatment of FA can be found in several reference books (e.g. Johnston, 1980; and Davis, 1984). The FA is performed with the help of SPSS package (1990).

\section{Results and Discussion}

The FA results are summarized in Table 2. Generally the FA gives factors in an equal number of variables employed. In practice, there are no rules to select the proper number of factors to retain. In the present study, however, the criteria for selecting the number of factors essentially depends on the scree-plot test (Johnston, 1980). It starts by plotting the eigenvalues in descending order of magnitude, is shown on Fig. 5. The diagram shows a distinct break between the steepness of the high eigenvalues and the gradual trailing off of the rest of the 
factors. In Fig. 5 , it appears that five factors might be assumed to represent, adequately, the overall variance of the data set. However, the five factors retained account for $81.4 \%$ of the total variance, while the remaining 14 factors together account for only $18.6 \%$ of the total variance. On the other hand, the high communalities indicate that most of the variance of each variable is explained by the factors extracted. Loadings less than 0.2 have been omitted from the table, since they are corresponding, approximately, to less than $5 \%$ of a variable.

TABLE 2. Factor loadings and communalities for the groundwater chemistry.

\begin{tabular}{|c|c|c|c|c|c|c|}
\hline \multirow{2}{*}{ Variables } & \multicolumn{5}{|c|}{ Factor loading } & \multirow{2}{*}{ Communality } \\
\hline & $\mathrm{F} 1$ & $\mathrm{~F} 2$ & F3 & F4 & F5 & \\
\hline $\mathrm{Ca} 2+$ & -0.819 & & 0.410 & & & 0.880 \\
\hline $\mathrm{Mg} 2+$ & 0.933 & & & & & 0.958 \\
\hline $\mathrm{Na}+$ & 0.904 & & 0211 & & & 0.899 \\
\hline $\mathrm{K}+$ & -0.770 & & & & & 0.642 \\
\hline $\mathrm{HCO}-3$ & -0.320 & 0.69 & -0.490 & & & 0.873 \\
\hline SO42- & 0.422 & & 0.680 & & & 0.681 \\
\hline $\mathrm{Cl}-$ & 0.939 & & & & & 0.944 \\
\hline NO-3 & & & & 0.869 & & 0.830 \\
\hline $\mathrm{PH}$ & -0.360 & 0.831 & -0.220 & & & 0.882 \\
\hline $\mathrm{Fe} 2+$ & 0.546 & & -0.418 & -0.611 & & 0.880 \\
\hline $\mathrm{NH}+4$ & & & -0.590 & -0.430 & & 0.590 \\
\hline PO43- & & & & 0.651 & -0.461 & 0.684 \\
\hline $\mathrm{SiO} 2$ & 0.235 & & & & 0.849 & 0.805 \\
\hline SIh & -0.830 & & & & & 0.740 \\
\hline SIc & & 0.942 & & & & 0.925 \\
\hline SId & & 0.955 & & & & 0.937 \\
\hline SIg & 0.483 & & 0.837 & & & 0.977 \\
\hline Temp. & -0.227 & & & -0.290 & 0.832 & 0.844 \\
\hline $\mathrm{EC}$ & 0.921 & & & & & 0.939 \\
\hline Eigenvalues & 6.06 & 3.06 & 2.31 & 1.97 & 1.65 & \\
\hline Percent of variance & 34.0 & 16.1 & 12.16 & 10.37 & 8.70 & \\
\hline Cumulative percent of variance & 34.0 & 50.10 & 62.30 & 72.7 & 81.4 & \\
\hline
\end{tabular}




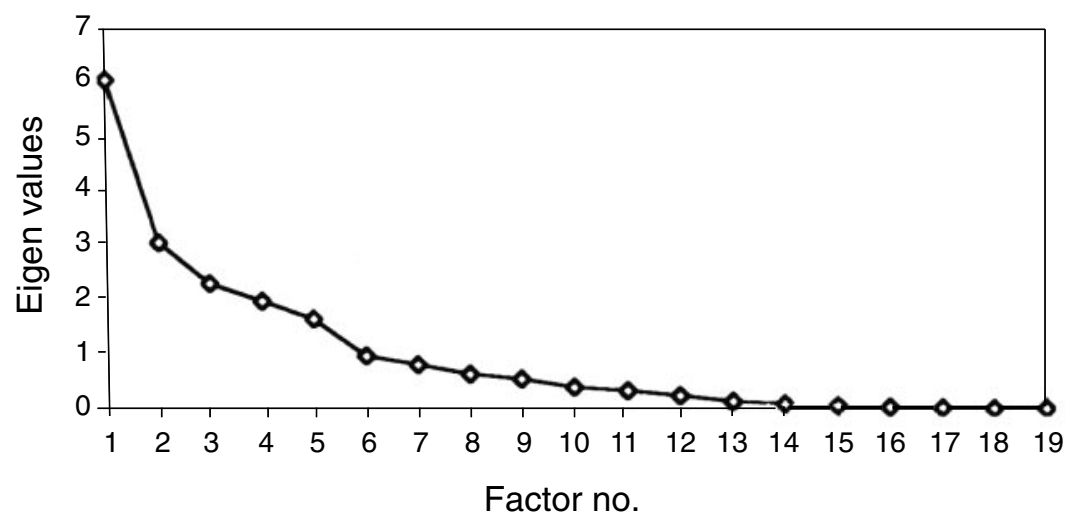

FIG. 5. Screen plot test.

The nature of the factors extracted for the system is discussed below:

Factor 1 accounts for $34 \%$ of the total variance. It is characterized by high positive loadings for $\mathrm{Cl}^{-}, \mathrm{Mg}^{2+}$, salinity and $\mathrm{Na}^{+}$and high negative loading for $\mathrm{Ca}^{2+}, \mathrm{K}^{+}$and $\mathrm{SI}_{\mathrm{h}}$. On the other hand, $\mathrm{Fe}^{2+}, \mathrm{SO}_{4}^{2-}, \mathrm{HCO}_{3}^{-}$and $\mathrm{SI}_{\mathrm{g}}$ have moderate loadings. Examination of these variable loadings indicates that different chemical controls might be operating either individually and/or collectively to cause an increase in the ionic concentrations of the groundwater. Therefore, the combination of these elements shows that factor 1 is most likely associated with the degree of overall mineralization of groundwater which is effectively derived from high rates evaporation and dissolution processes. The importance of the evaporation process is indicated by the dominance of $\mathrm{Cl}^{-}$ion concentrations (Table 1). This process could concentrate certain ions to the point that can be precipitated as solid phase minerals. This conclusion is of great importance, since the abundance of $\mathrm{Cl}^{-}$ions cannot be justified by the weathering of the rockforming minerals. Moreover, the XRD analysis of the soil samples indicated that calcite, dolomite and gypsum with small amount of halite are very common evaporitic salts in surficial soils. Although, evaporation process has probably the greatest influence in determining the groundwater salinity, other processes are also believed to be influencing the actual chemical composition but the high concentration of ions could mask such processes. These include the net addition of $\mathrm{K}^{+}, \mathrm{Ca}^{2+}, \mathrm{Mg}^{2+}$ and $\mathrm{HCO}_{3}^{-}$. The moderate loadings of these elements could be attributed to their release into the groundwater by weathering of silicate minerals.

The diorite rocks, which are the dominant rock unit in the area, could be considered as major contributor of $\mathrm{Ca}^{2+}, \mathrm{Mg}^{2+}, \mathrm{K}^{+}$and $\mathrm{Fe}^{2+}$, since these rocks commonly contain hornblende and biotite as the major rock-forming minerals. It is not surprising; therefore, that as groundwater travels through these rocks as 
well as sediments derived from these rocks dissolves the chemically-altered products. The chemical weathering process may also be considered as a supplier source of $\mathrm{HCO}_{3}^{-}$and $\mathrm{SiO}_{2}$ which are released into solution due to the weathering reactions. Surprisingly, $\mathrm{SiO}_{2}$ is not significantly loaded on this factor but is primarily associated with factor 5 . However, $\mathrm{Fe}^{2+}$ and $\mathrm{HCO}_{3}^{-}$ions appear in other factors (Table 2), which implies multiple controls. On the other hand, the high concentrations of $\mathrm{Na}^{+}$and $\mathrm{Ca}^{2+}$ in the groundwater (Table 1), and their opposite loadings on this factor are probably best explained through cation exchange reactions. There is little evidence of salt water intrusion, nevertheless, its influence cannot be ruled out, especially in areas adjacent to the sea coast. Few samples taken from these areas have a chemical composition similar or exceeding that of the Red Sea water (see Fig.3).

Factor 2 represents $16.1 \%$ of the total variance. Saturation indices of calcite and dolomite, $\mathrm{HCO}_{3}^{-}$as well as $\mathrm{pH}$ show high loadings in this factor. These elements most likely control and reflect dissolution and precipitation of carbonate minerals.

Factor 3 accounts for $12.2 \%$. It has high positive loadings for $\mathrm{SI}_{\mathrm{g}}$ and $\mathrm{SO}_{4}^{2-}$ with a relatively high negative loading of $\mathrm{HCO}_{3}^{-}, \mathrm{Fe}^{2+}$, and $\mathrm{Ca}^{2+}$ are also loaded in this factor. The opposition between $\mathrm{SO}_{4}^{2-}$ and $\mathrm{HCO}_{3}^{-}$probably reflects a competition between these two anions in reacting with $\mathrm{Ca}^{2+}$; namely precipitating and/or dissolving gypsum and calcite minerals. The appearance of $\mathrm{Fe}^{2+}$ in this factor may indicate oxidation of pyrite $\left(\mathrm{FeS}_{2}\right)$, which is a very common accessory mineral in the igneous rocks. This may contribute to the releasing of $\mathrm{Fe}^{2+}$ and $\mathrm{SO}_{4}^{2-}$ into the groundwater. The moderate negative loading of $\mathrm{NH}_{4}^{+}$in this factor may indicate less oxygenated pathway owing to oxidation of pyrite (Lawrence and Upchurch 1982).

Factor 4 includes relatively high negative loadings of $\mathrm{NO}_{3}^{-}$and $\mathrm{Fe}^{2+}$ and moderate positive loadings for $\mathrm{PO}_{4}^{3-}$ and $\mathrm{NH}_{4}^{+}$. Most of these elements have no significant lithologic sources in the study area and are often associated with groundwater pollution. The appearance of $\mathrm{NH}_{4}^{+}$in this factor has probably affected the $\mathrm{NO}_{3}^{-}$concentration by reducing nitrogen compound.

Factor 5 represents $8.7 \%$ of the total variance. $\mathrm{SiO}_{2}$ and groundwater temperature were highly loaded in this factor with moderate loading of $\mathrm{PO}_{4}^{3-}$. This factor indicates that groundwater temperature is possibly controlling the $\mathrm{SiO}_{2}$ solubility (Hem, 1970). The appearance of $\mathrm{PO}_{4}^{3-}$ in this factor is rather difficult to explain.

The relationships among the chemical variables (Fig. 6) show the location of the variables loadings in the space defined by F1 with F2, F3, F4 and F5 for the varimax rotation. 


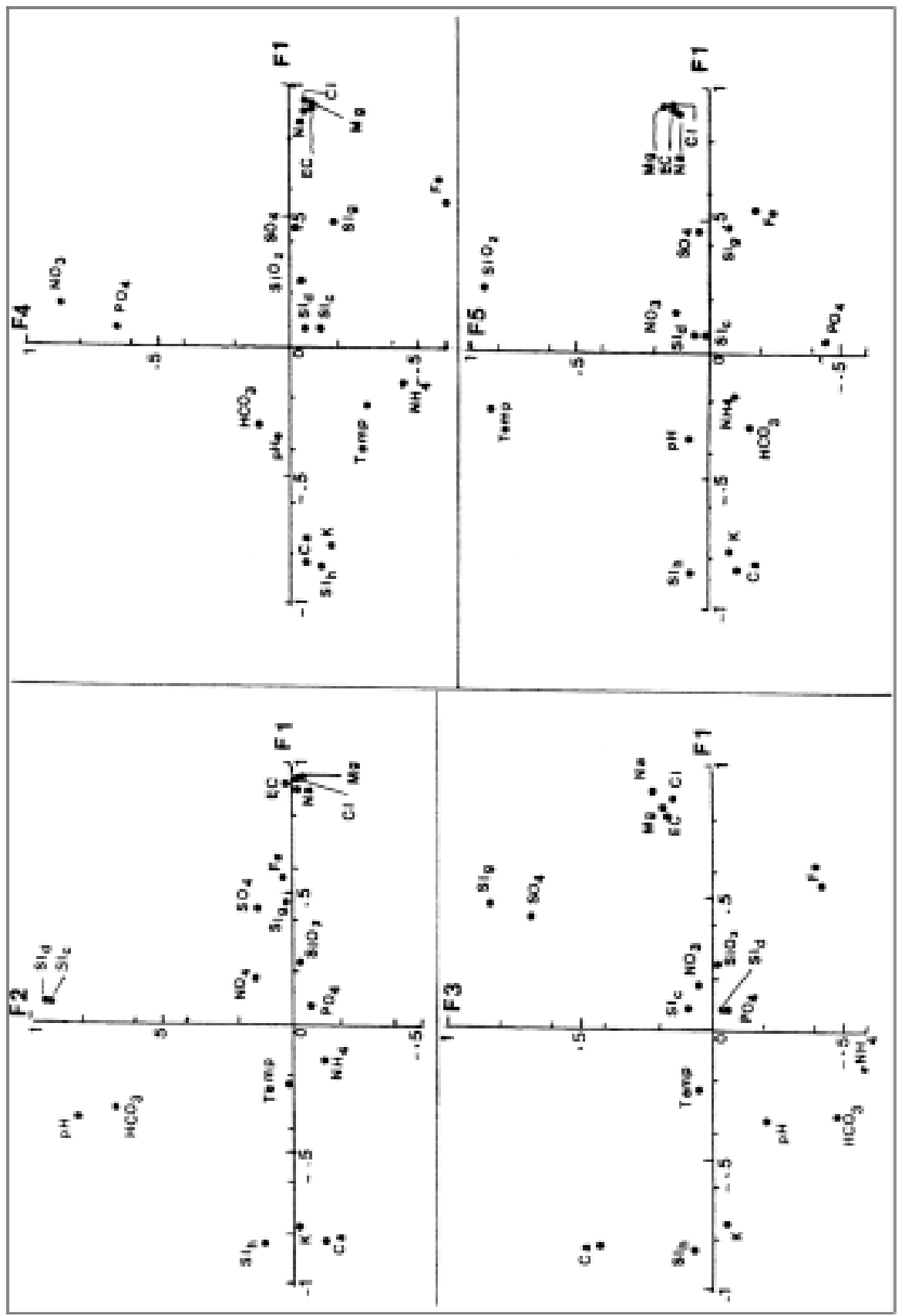

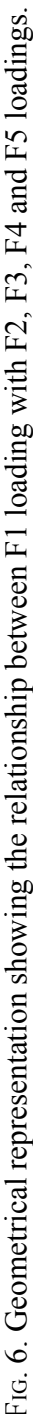


To assess the spatial importance of the factors extracted, scores of the first four factors were calculated and their distributions are illustrated in Figs. 7 to 10. Fig. 7 shows the aerial distribution of factor 1 . It can be noticed that high factor scores $(+\mathrm{ve})$ almost mark three regions; the southwestern, north and northwestern. In these parts, the water table is rather shallow and/or at the ground surface. Therefore, opportunities for direct evaporation are likely to occur. High saline waters were observed in these regions and evaporitic salts such as calcite, dolomite and gypsum were detected in the surficial soils. As a result, the chemical composition of the groundwater has been affected by these highly soluble salts that were washed down into the groundwater body by rain- and/or surface waters. On the other hand, negative factor scores almost characterize the central part of the study area. This area lacks sewage networks and is believed to be affected by mixing process throughout indirect supply from domestic usage as well as the subsurface inflow from the eastern wadis. Fresh water from such sources tends to mix with relatively saline water, consequently, leading to decreasing the overall groundwater salinity. In terms of the distribution of high and low scores, the distribution of factor 1 relatively matches that of TDS map (Fig. 3), confirming the occurrence of low and high salinity waters outlined previously.

Figure 8 shows the distribution scores of factor 2. From the map, two distinctive areas were recognized. Low factor scores almost characterize the northern region, this indicating a continuous dissolution process of limestone rocks (see Fig. 4), whereas, high positive scores existing the southern area, reflect precipitation of calcite and probably dolomite minerals. Fig. 9 shows the distribution of factor 3 scores. There are no areas dominated by singularly high or low factor scores, but mostly interfere pattern. Such case may be attributed to the availability of pyrite that a very accessory mineral observed in the alluvial sediments for oxidation and the precipitation/dissolution processes of gypsum and calcite minerals throughout a competition between $\mathrm{HCO}_{3}^{-}$and $\mathrm{SO}_{4}^{2-}$ in reaction with $\mathrm{Ca}^{2+}$ ions. Fig. 10, which displays the distribution of factor 4 , represents a pollution control. As shown from the map, the northeastern region is probably the most affected. The availability of pollution sources such as sewage liquid ponds, solid waste dump and livestock market can explain the higher factor scores. High $\mathrm{NO}_{3}^{-}$concentrations ranging between 90 to $586 \mathrm{mg} / \mathrm{l}$ were observed in the groundwater samples obtained from this area. The high contents, therefore, has probably increased by the two following sources; (i) infiltration from the waste water ponds; and (ii) from the livestock that could produce considerable amount of nitrogenous organic waste that tends to concentrate $\mathrm{NO}_{3}^{-}$ which is then leached by rainfall and surface runoff. Other regions may also have positive factor scores, but less affected than the previous area, indicating that domestic usage probably contributes to the overall $\mathrm{NO}_{3}^{-}$contents in the groundwater. 


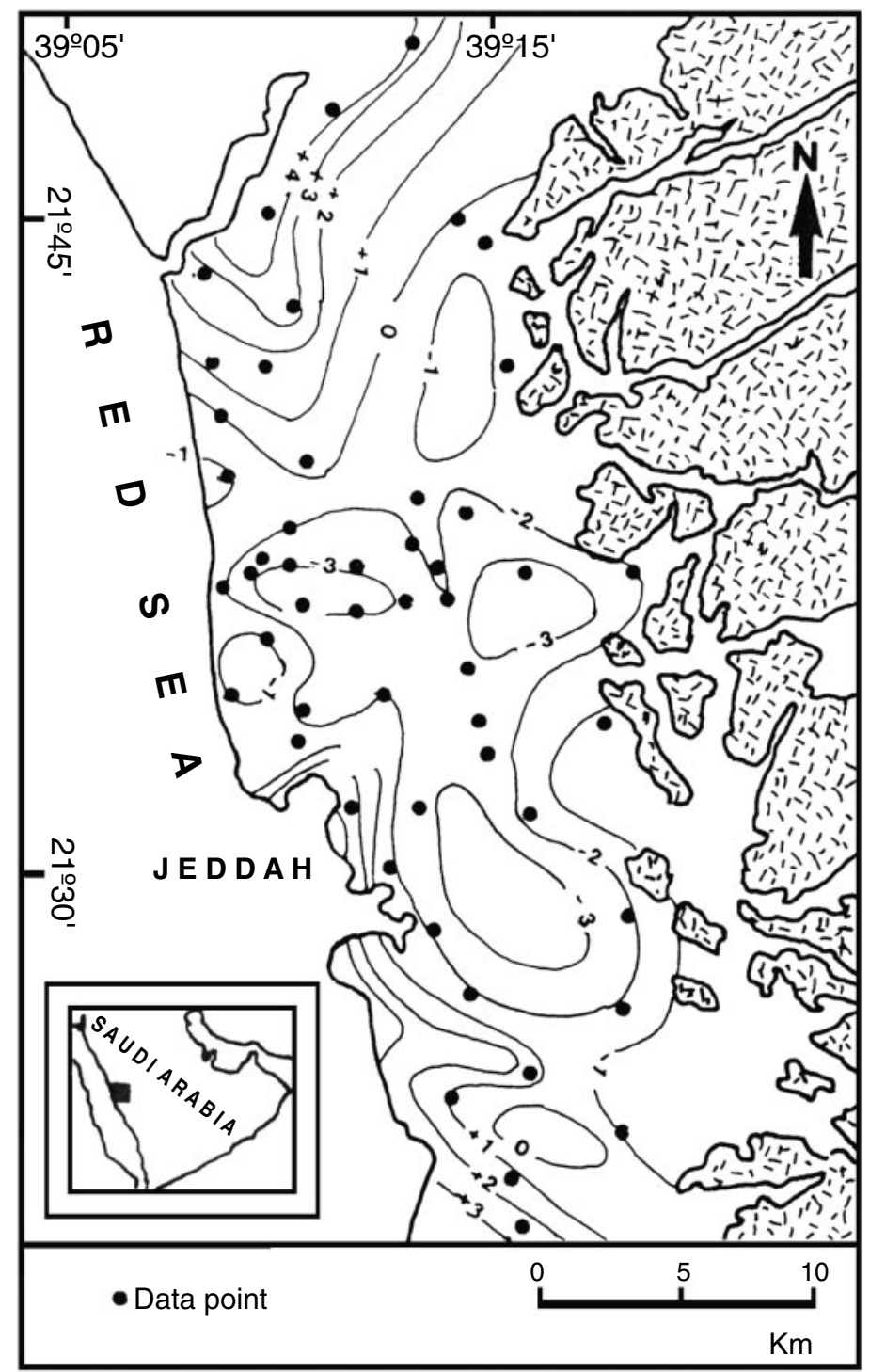

FIG. 7. Distribution map of factor 1 scores. 


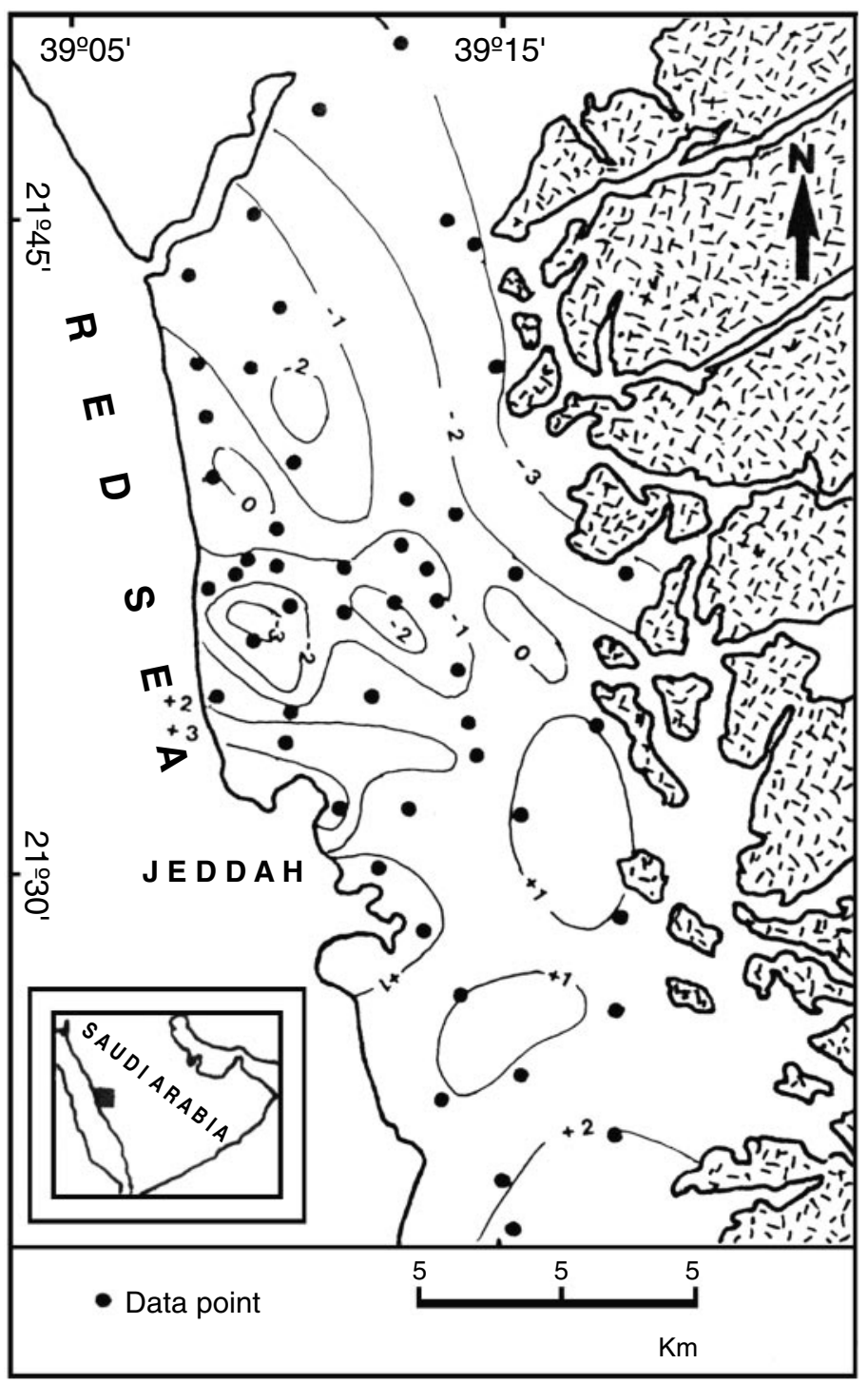

FIG. 8. Distribution map of factor 2 scores. 


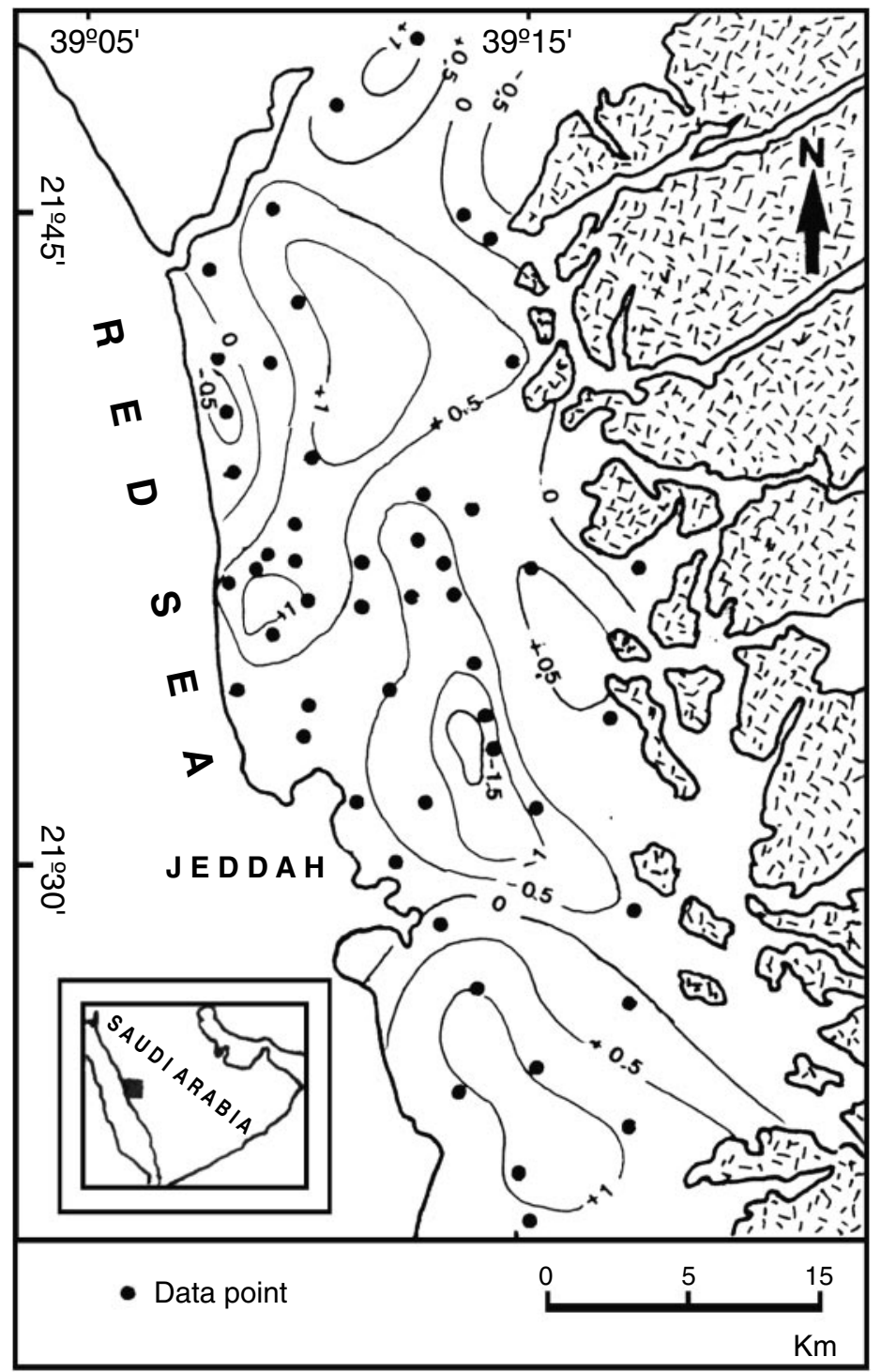

FIG. 9. Distribution map of factor 3 scores. 


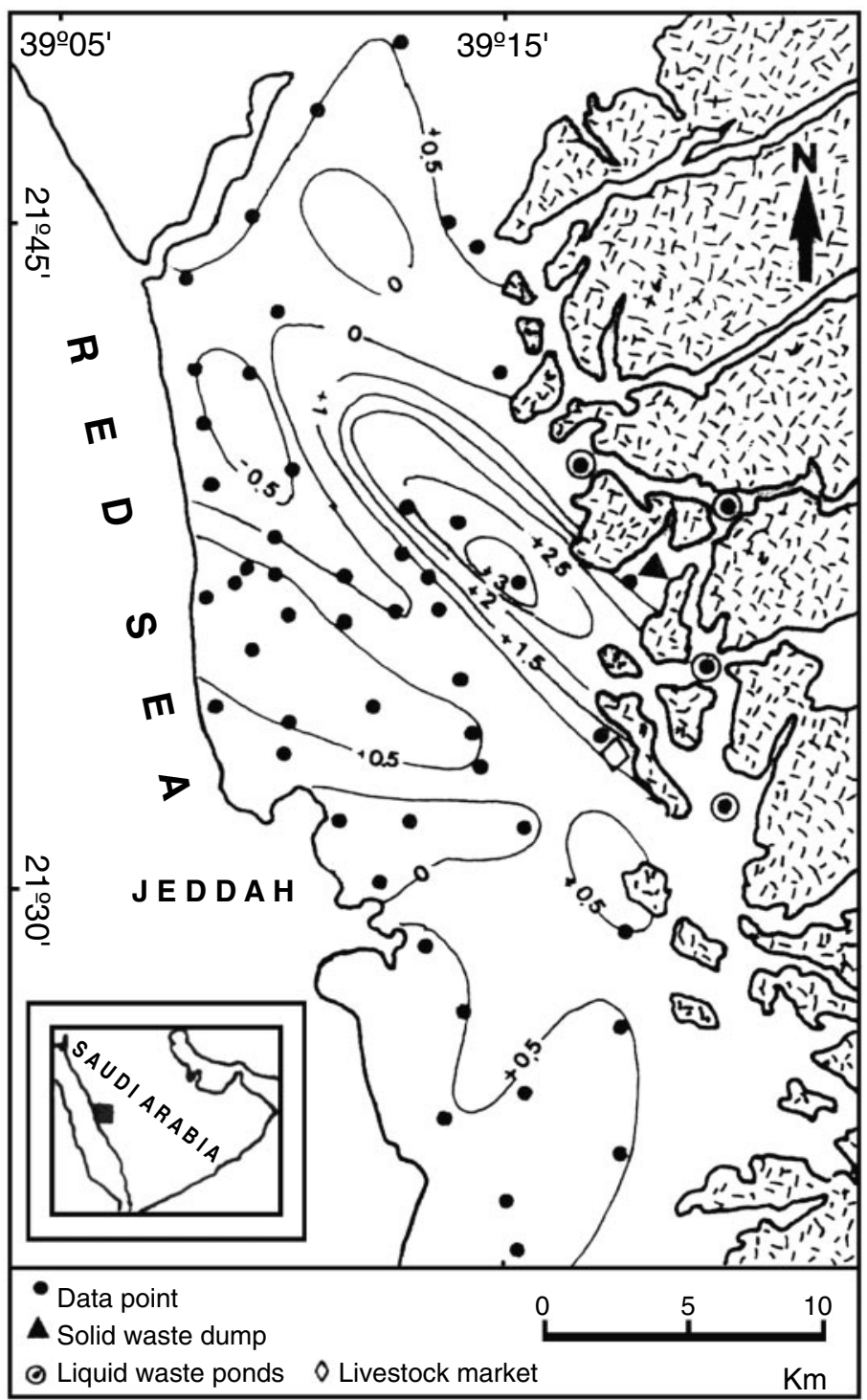

FIG. 10. Distribution map of factor 4 scores. 


\section{Conclusions}

The FA results show that factor 1 is basically associated with high degree of groundwater mineralization, which resulted from evaporation process, which is the most effective factor causing the groundwater salinity. Chemical weathering of silicate minerals, dilution due to mixing process between fresh water from domestic usage and the sub-surface inflow with high mineralized groundwater together with redistribution of $\mathrm{Na}^{+}$and $\mathrm{Ca}^{2+}$ contents throughout ion exchange reactions contribute to the overall chemical composition of the groundwater. Factor 2 is dominated by precipitation and dissolution of carbonate minerals processes (calcite and dolomite) caused by ground- and surface waters. It also accounts for controlling the relative proportions of $\mathrm{Ca}^{2+}, \mathrm{Mg}^{2+}$ and $\mathrm{HCO}_{3}^{-}$in the groundwater. However, both factors 1 and 2 may be considered the major factors affecting groundwater chemistry. Oxidation of pyrite may be regarded as a contributor source for $\mathrm{SO}_{4}^{2-}$ and $\mathrm{Fe}^{2+}$. Factor 4 may reflect the groundwater pollution within the study area. The FA results show the strong effect of groundwater temperature on the solubility of silica. The appearance of $\mathrm{Ca}^{2+}$, $\mathrm{Fe}^{2+}, \mathrm{SO}_{4}^{2-}$ and $\mathrm{HCO}_{3}^{-}$in different factors indicates that multi-chemical processes are controlling these ions. Factor scores distribution maps provide a general picture of highly affected areas by these factors.

\section{References}

Al-Quahtani, M.B. (1998) Engineering geology of Jeddah metropolitan. Ph.D Thesis, Faculty of Earth Sci., King Abdulaziz Univ., Jeddah, Saudi Arabia, 335 p.

Ashley, R.P. and Lloyd, J.W. (1978) An Example of the Use of Factor and Cluster Analysis in Groundwater Chemistry Interpretation. J. Hyd. 39: 355-364.

Basamed, A.S. (2001) Hydrochemical Study and Bacteriological Effects on Groundwater in The Northern Part of Jeddah District. Unpublished M.Sc. Thesis. Faculty of Earth Sci., King Abdulaziz Univ., Jeddah, Saudi Arabia, 234 p.

Bayumi, T.H, Alyamani, M.S, Alsubyani, A.M, Aldakheel, A.M. and Alahamadi, M.E. (2000) Analytical Study of Flood Problem and Groundwater Rise in the Jeddah District. Project No. 606/418, Final report Scientific Res. Council, King Abdulaziz Univ., Jeddah, Saudi Arabia, $229 \mathrm{p}$.

Dalton, M.G. and Upchurch, S.B. (1978) Interpretation of Hydrochemical Facies by Factor Analysis. Groundwater, 16(4): 228-233.

Davis, J.C. (1984) Statistics and Data Analysis in Geology. 2nd ed., John Wiley and Sons., Inc., New York, $646 \mathrm{p}$.

Deverel, S.J. (1989) Geostatistical and Principal Components Analysis of Groundwater Chemistry and Soil Salinity Data. San Joaquin Valley, California. Proceeding of the Baltimore Symposium. Regional Characterisation of Water Quality.

Hacker, P., Hotzel, H., Moser, H., Rauret, W., Ronner, F. and Zotal, J.G. (1984) Region around Jeddah and its hinterland. In: Jado, A. and Zotal, J.G., (eds.). Quaternary period of Saudi Arabia, Vol.2. Springer-Verlag, Wien New York: 107-141.

Hem, J.D. (1970) Study and Interpretation of the Chemical Characteristics of Natural Water. 2ed Ed. USGS Water Supply paper 1473, Washington, 363 p. 
Johnston, R.K. (1980) Multivariate Statistical Analysis in Geography. Longman Inc., New York, $280 \mathrm{p}$.

Klovan, J.E. (1975) R-mode and Q-mode factor Analysis, in: McCammon, R.B. (ed) Concepts in Geostatistics, Springer-Verlag, New York, 168 p.

Lawrence, F.W. and Upchurch, S.B. (1982) Identification of Recharge Areas Using Geochemical Factor Analysis. Groundwater, 20(6): 680-687.

Moore, T.G. and Al-Rehaili, M.H. (1989) Geologic map of the Makkah quadrangle, Sheet 21D, Kingdom of Saudi Arabia: Saudi Arabian Dir. Gen. Min. Res. Geoscience map GM-107C.

Morin, G., Fortin, J.P., Sochanska, W., Lardeau, J.P. and Charbonneau, R. (1979) Use of Principal Component Analysis to Identify Homogeneous Precipitation Stations for Optimal Interpretation. Water Resour. Res., 15(6): 1841-1850.

Saad, M. and Turgeon, A. (1988) Application of Principal Component Analysis to Long-Term Reservoir Management. Water Resour. Res., 24(7): 907-912.

SPSS Inc. (1990) SPSS/PC $C^{+}$, Advance Statistics, Marketing Department, Chicago, IL60611.

Usunoff, E.J. and Guzman, A. (1989) Multivariate Analysis in Hydrochemistry: An Example of the Use of Factor and Correspondence analysis. Groundwater, 27(1): 27-34. 


\section{استخدام تحليل العوامل في التعرف على المصادر التي تتحكم في كيمياء المياه الجوفية في الخزان المائي الجوفي الضحل في السهل الساحلي، غرب المملكة العربية السعودية}

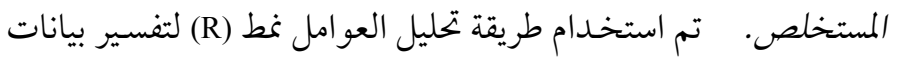

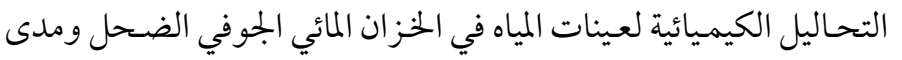

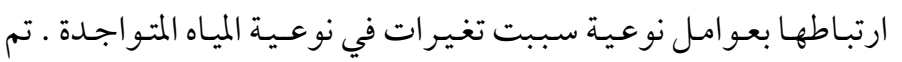

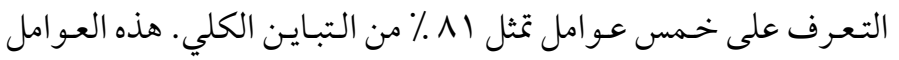

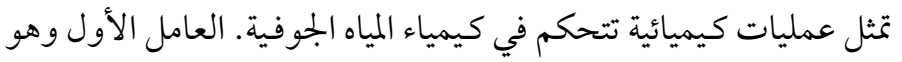

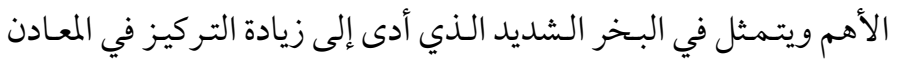

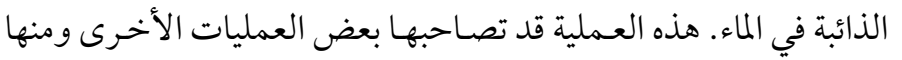

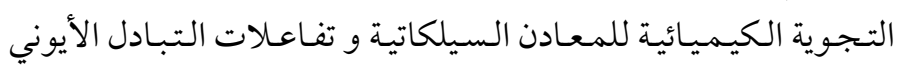

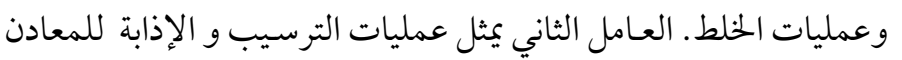

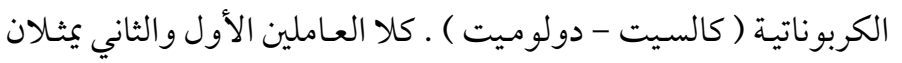
ما نسبته • 0 ٪ من التباين الكلي أي أنه يكن اعتبارهما العاملين الرئيسيين

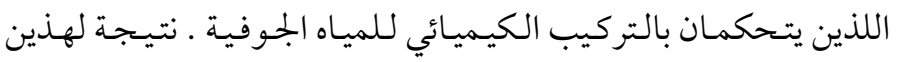

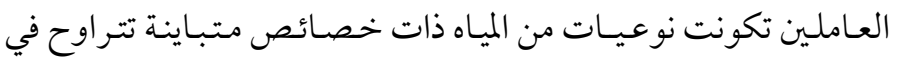

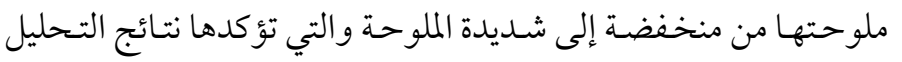

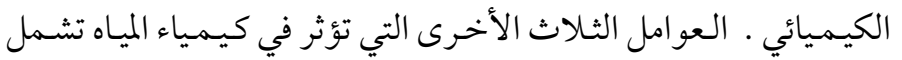

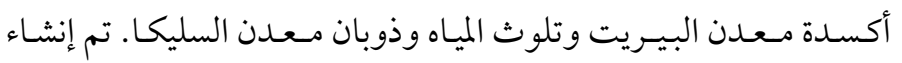
خر ائط توضح توزيع نتائج العوامل الأربعة الأولى لتحديد التأثير المكاني النسبي لتلك العوامل. 